\title{
Relationship between stand density and value of timber assortments: a case study for Scots pine stands in north-western Poland
}

\author{
Andrzej Węgiel ${ }^{1^{*}}$ (D), Mariusz Bembenek ${ }^{2}$, Agnieszka Łacka ${ }^{3}$ and Piotr S Mederski²
}

\begin{abstract}
Background: Stand density changes during forest growth. Various types and intensities of thinning operations can be applied in order to improve the volume of the remaining trees. It is not clear whether or not thinning results in better total volume increment although timber value is usually higher when thicker logs are obtained from trees. The objective of this study was to determine if Scots pine (Pinus sylvestris L.) stands of lower density would produce timber of a higher value than stands with a higher density and thinner trees.

Methods: The research was carried out on 20 experimental plots in 81-90-year-old Scots pine stands, located in northwestern Poland. The data obtained were used to simulate the logging of the trees into either $2.5-\mathrm{m}$ logs or tree tops, which were classified into five quality classes of timber. The volume of each assortment was calculated, based on its dimensions, and the value in EUR was calculated.

Results: It was found that the correlation between stand density and the total value of the wood was very weak and not statistically significant. However, taking each assortment separately, the values of sawmill wood, pulpwood and energy wood were significantly correlated with stand density.

Conclusions: It was concluded that lower densities were more profitable for sawmill wood production, while higher densities might be more beneficial in biomass production.
\end{abstract}

Keywords: Forest management, Pinus sylvestris, Stand volume, Basal area, Tree diameter

\section{Background}

The main goals in timber production are to increase stand growth or improve its quality on a sustainable basis. The control of stand density by thinning and by initial spacing is a major tool for achieving this goal. Stand density is one of only a few factors that can be controlled efficiently for profit. In short, according to Zeide (2004), forestry is the science of stand density optimisation.

Thinning reduces stand density and increases resource availability to the remaining trees, thus improving their growth (Giuggiola et al. 2013; Kojola et al. 2012; Tahvonen et al. 2013). Therefore, the impact of thinning on stand

\footnotetext{
* Correspondence: wegiel@up.poznan.pl

${ }^{1}$ Faculty of Forestry, Department of Forest Management, Poznań University of Life Sciences, Wojska Polskiego 71C, 60-625 Poznań, Poland Full list of author information is available at the end of the article
}

productivity has been extensively studied. Research includes findings from multi-annual thinning experiments as well as results based on large inventory data sets from regular commercial forests (Borecki et al. 2016; Castedo-Dorado et al. 2009; Curtis et al. 1997; Mäkinen et al. 2005; Mäkinen and Isomäki 2004a; Nilsson et al. 2010; Zeide 2001). These studies focused mainly on a comparison of volume growth between stands subjected to thinning operations of different intensities and unthinned control plots. The results obtained have been contradictory, and there has been long-standing controversy as to whether an optimum stand density can be found or whether unthinned stands with a high density are the most productive (Zeide 2004).

Research indicates that thinning intensity is particularly significant for forest growth (Mäkinen et al. 2005). Heavy thinning was usually associated with a lower 
stand volume increment than that found on unthinned control plots (del Río et al. 2008; Mäkinen and Isomäki 2004a; Valinger et al. 2000). For light thinning, weak or no correlations were found (del Río et al. 2008; Zhang et al. 2007). Other studies found that, immediately after thinning, there was a decrease in stand volume growth, typically lasting approximately 10 years, levelling off after this period (Egnell and Ulvcrona 2015). In addition, greater tree volume growth occurred in the remaining trees if thinning were heavier (Gizachew and Brunner 2011; Kuliešis et al. 2010; Moulinier et al. 2015). Notably, however, the growth of those trees that remain after heavy thinning or those grown at an initial low density may have poorer wood quality than trees grown at higher densities. Wood qualities affected include wood density, the compressive strength, the modulus of rupture and the strength quality coefficient (Czajka and Fabisiak 2016; Mederski et al. 2015).

In some studies, the authors found no significant impact of thinning on stand productivity (del Río et al. 2008; Giuggiola et al. 2013; Gizachew and Brunner 2011) or total biomass growth (Routa et al. 2012). Furthermore, some studies have found that merchantable volume increment remained unchanged or was even higher when stand volume increment decreased as thinning intensity increased (Curtis et al. 1997; Niemistö 2013; Nilsson et al. 2010; Tahvonen et al. 2013; Zeide 2001).

The equivocal (or even contradictory) reports on the impact of thinning on stand productivity by various authors may result from differences in experimental conditions and site quality, the species studied, environmental factors, and a diversity in the definitions of density and volume (cumulative, gross, net, total, merchantable) (Zeide 2001). Changes in forestry treatments over time have also been substantial, including, for example, changes in initial spacing, changes in thinning frequency and intensity, and adjustments to the mechanisation of forest harvesting operations (Mäkinen et al. 2005; Nilsson et al. 2010).

Most studies on the effect of stand density on productivity have used stand volume increment (in cubic metres) as the measure of productivity. Economically, however, production optimisation should be based on the value of the products, in particular timber assortments (Alegria 2011; Nilsson et al. 2010; Tahvonen et al. 2013; Zeide 2001).

Scots pine (Pinus sylvestris L.) has the largest geographic distribution of all pine species and is probably the most widely distributed coniferous species in the world (Tahvonen et al. 2013). It is also an economically important species (e.g. Giuggiola et al. 2013; Mäkinen and Isomäki 2004b; Valinger et al. 2000). Despite numerous studies on pine stand volume increment, few publications so far have focused on the economic aspects of
Scots pine management (e.g. Hurttala et al. 2017; Hyytiäinen et al. 2006; Pasalodos-Tato and Pukkala 2007; Tahvonen et al. 2013).

The present paper is based on the hypothesis that Scots pine stands of similar age growing under similar habitat and climate conditions, and only distinguished by tree density, will have similar volumes and basal areas, but the value of the products obtained will be higher in the case of lower-density stands.

The objective of the study was to identify correlations between the main parameters of a stand, i.e. diameter at breast height ( $\mathrm{dbh}$ ), tree height, stand volume and basal area, and the total value of the timber assortments obtained from the stand. The assortments analysed included sawmill wood, pulpwood and energy wood, and the analysis was performed in mature commercial Scots pine stands of various densities, ranging from 476 to 836 trees per hectare.

\section{Methods}

The research was carried out on 20 sample plots in Scots pine stands (one plot per stand), located in the Drawno Forest District (Fig. 1), in north-western Poland (E $\left.15^{\circ} 50^{\prime}-16^{\circ} 0^{\prime}, \mathrm{N} 53^{\circ} 10^{\prime}-53^{\circ} 13^{\prime}\right)$. The stands were all located in the same complex, established as planted forest, and grown under the same climatic conditions. The average annual rainfall in this area is $589 \mathrm{~mm}$, the average temperature is $7{ }^{\circ} \mathrm{C}$ and the growing season lasts 200-220 days. It can be assumed that the stands had been established in a similar way (the same initial spacing) and similarly managed (the same owner and manager). Since 1945, the stands have been managed by the State Forests National Forest Holding, and, up until the present day, stands have been thinned once per decade. In the last period, positive thinning was applied to generate the best possible growing conditions for the remaining dominant trees. The experimental plots, 0.5 ha each (Table 1), were selected so as to make tree density the distinguishing variable.

The plots were established in even-aged, 81-90-year-old, single-species, single-layer stands, growing on the same soil type, classified as Carbic Podzols. The stands had not been thinned over the previous 5 years. In the sample plots, all the diameters at breast height (dbh) were measured (each tree on each plot) and, for $20 \%$ of the trees (every fifth tree), the height was also measured. Based on this data, Näslund's height curves were developed to establish the height of the trees in sampled stands (Näslund 1929).

$$
h=\frac{d^{2}}{\left(k_{1}+k_{2} d\right)^{2}}+1.3
$$

$d$-diameter at breast height $(\mathrm{cm})$ 


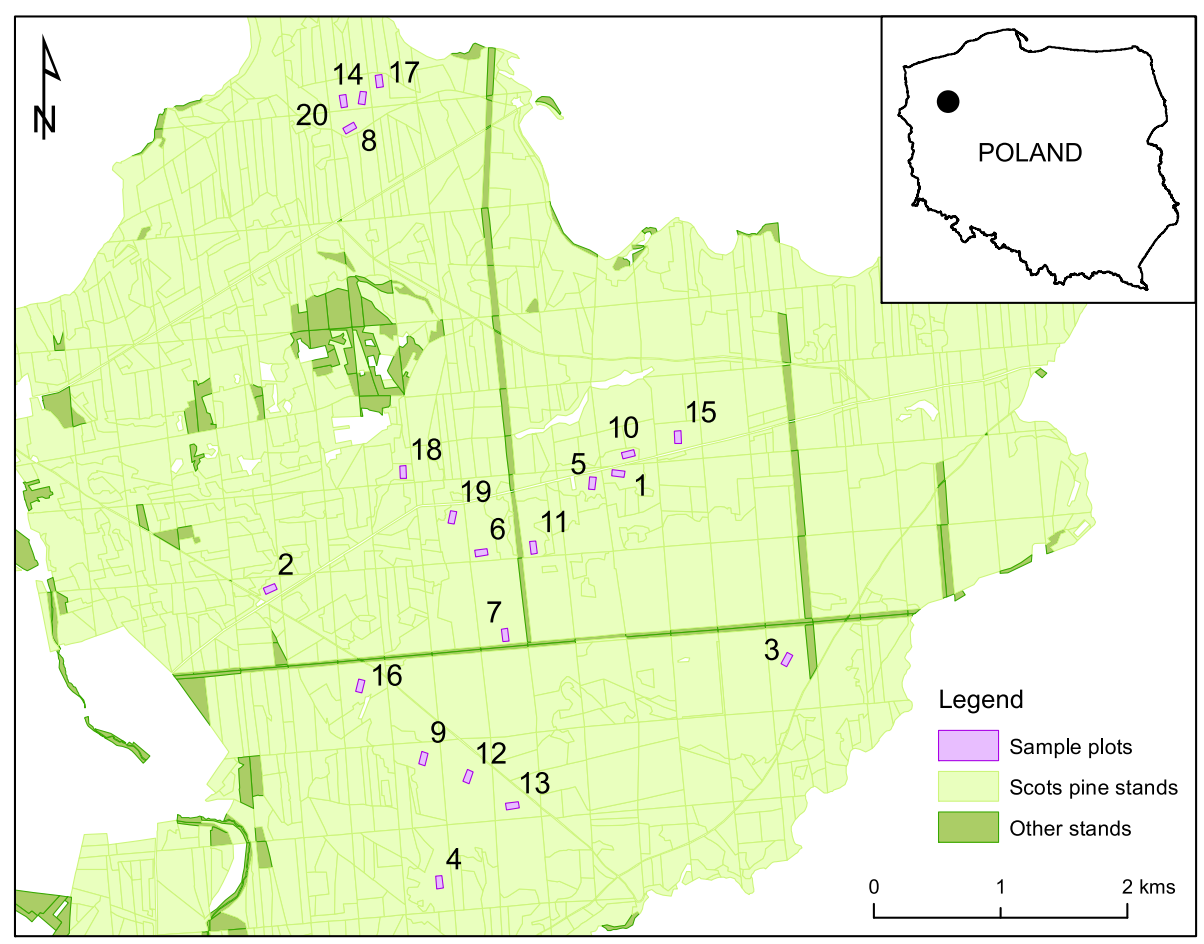

Fig. 1 South-eastern part of the Forest District Drawno; distribution of sample plots

Table 1 Stand characteristics of sample plots (0.5 ha) selected for the study

\begin{tabular}{|c|c|c|c|c|c|c|c|c|c|}
\hline $\begin{array}{l}\text { Sample } \\
\text { plot }\end{array}$ & $\begin{array}{l}\text { Age, } \\
\text { years }\end{array}$ & $\begin{array}{l}\text { Density, } \\
\text { tree ha }^{-1}\end{array}$ & $\begin{array}{l}\text { Relative } \\
\text { spacing }\end{array}$ & $\begin{array}{l}\text { Arithmetic mean dbh } \\
( \pm S D), \mathrm{cm}\end{array}$ & $\begin{array}{l}\text { Quadratic mean } \\
\mathrm{dbh}, \mathrm{cm}\end{array}$ & $\begin{array}{l}\text { Mean height } \\
( \pm S D), m\end{array}$ & $\begin{array}{l}\text { Top } \\
\text { height, m }\end{array}$ & $\begin{array}{l}\text { Basal area, } \\
\mathrm{m}^{2} \mathrm{ha}^{-1}\end{array}$ & $\begin{array}{l}\text { Merchantable } \\
\text { volume, } \mathrm{m}^{3} \mathrm{ha}^{-1}\end{array}$ \\
\hline 1 & 82 & 476 & 0.19 & $28.2 \pm 4.5$ & 28.6 & $22.9 \pm 1.7$ & 24.5 & 30.5 & 319 \\
\hline 2 & 87 & 518 & 0.17 & $27.5 \pm 4.9$ & 27.9 & $23.6 \pm 2.0$ & 25.6 & 31.8 & 344 \\
\hline 3 & 82 & 534 & 0.18 & $25.9 \pm 4.3$ & 26.2 & $22.4 \pm 1.5$ & 24.1 & 28.4 & 293 \\
\hline 4 & 82 & 564 & 0.16 & $28.0 \pm 4.5$ & 28.3 & $24.5 \pm 1.4$ & 26.2 & 35.5 & 394 \\
\hline 5 & 82 & 594 & 0.18 & $25.7 \pm 4.7$ & 26.1 & $20.8 \pm 1.4$ & 22.6 & 31.5 & 301 \\
\hline 6 & 82 & 596 & 0.18 & $27.1 \pm 5.2$ & 27.6 & $21.6 \pm 1.4$ & 23.4 & 35.7 & 352 \\
\hline 7 & 82 & 618 & 0.18 & $24.6 \pm 4.0$ & 24.9 & $20.4 \pm 1.5$ & 22.0 & 30.2 & 283 \\
\hline 8 & 82 & 632 & 0.17 & $24.0 \pm 4.7$ & 24.5 & $21.1 \pm 1.4$ & 22.9 & 29.6 & 288 \\
\hline 9 & 82 & 632 & 0.17 & $25.6 \pm 4.7$ & 26.0 & $22.0 \pm 1.4$ & 23.9 & 33.6 & 341 \\
\hline 10 & 82 & 634 & 0.17 & $24.6 \pm 4.6$ & 25.1 & $21.4 \pm 1.6$ & 23.1 & 31.0 & 305 \\
\hline 11 & 82 & 640 & 0.16 & $26.0 \pm 4.7$ & 26.4 & $23.4 \pm 1.7$ & 25.4 & 35.1 & 378 \\
\hline 12 & 82 & 644 & 0.16 & $26.4 \pm 4.4$ & 26.7 & $23.0 \pm 1.4$ & 24.7 & 35.9 & 377 \\
\hline 13 & 82 & 648 & 0.16 & $25.9 \pm 5.2$ & 26.5 & $22.3 \pm 1.7$ & 24.5 & 35.4 & 366 \\
\hline 14 & 82 & 674 & 0.18 & $23.6 \pm 4.3$ & 24.0 & $19.6 \pm 1.5$ & 21.5 & 30.1 & 275 \\
\hline 15 & 82 & 682 & 0.15 & $24.7 \pm 4.9$ & 25.2 & $22.8 \pm 1.7$ & 24.9 & 34.0 & 357 \\
\hline 16 & 82 & 708 & 0.18 & $21.8 \pm 4.2$ & 22.2 & $19.5 \pm 2.2$ & 21.6 & 27.3 & 246 \\
\hline 17 & 82 & 720 & 0.14 & $22.3 \pm 4.3$ & 22.7 & $24.7 \pm 3.8$ & 27.4 & 29.1 & 339 \\
\hline 18 & 82 & 756 & 0.16 & $21.7 \pm 4.4$ & 22.2 & $20.5 \pm 2.0$ & 22.6 & 28.9 & 276 \\
\hline 19 & 82 & 758 & 0.16 & $23.9 \pm 5.3$ & 24.4 & $20.1 \pm 2.0$ & 22.3 & 35.7 & 334 \\
\hline 20 & 82 & 836 & 0.16 & $21.8 \pm 4.0$ & 22.1 & $19.3 \pm 1.7$ & 21.4 & 31.5 & 286 \\
\hline
\end{tabular}


$h$-height of the tree $(\mathrm{m})$

The parameters $k_{1}$ and $k_{2}$, determined for Scots pine in Poland by Rymer-Dudzińska (1994), were used in the equation.

$$
\begin{aligned}
& k_{1}=\frac{D}{\sqrt{H-1.3}}-k_{2} D \\
& k_{2}=0.7445 H^{-0.4531}
\end{aligned}
$$

$D$-mean diameter of the stand $(\mathrm{cm})$

$H$-mean height of the stand (m)

Every tree was then assigned its individual height derived from the curve. The goodness of fit of the model was determined by the coefficient of determination $\left(R^{2}\right)$. For Näslund's height curves of the 20 sample plots, $R^{2}$ ranged from 0.703 to 0.986 (mean $=0.849$, standard deviation $=0.078$ ).

A database was then created based on the measurements, comprising information on all the trees in the 20 experimental plots (6393 trees in total). Subsequently, the data were used to simulate the classification of the trees into assortments (2.5-m logs and tree tops). These were classified into one of five timber assortments based on the measurements (Table 2).

For this purpose, the diameters of the logs (under the bark) at the large and small ends and in the middle were calculated. The dbh under the bark was calculated using the dbh measured over the bark and a modifier determined empirically by Bruchwald (1969) for Scots pine in the same forest complex (Drawska Forest).

The stem diameter at any height was calculated based on the dbh and tree height, using the taper model developed by Lee et al. (2003).

$$
d x=k_{1} d^{k_{2}}(1-z)^{r_{1} z^{2}+r_{2} z+r_{3}}
$$

$d x$-stem diameter at height $h x(\mathrm{~cm})$

$d$-diameter at breast height $(\mathrm{cm})$

relative height: $z=h x / h$

$h x$-height along the stem (m) above ground

$h$-total height of the tree $(\mathrm{m})$

The following parameters, determined for Scots pine by Petrauskas et al. (2011), were used in the equation: $k_{1}=1.6102, \quad k_{2}=0.9025, \quad r_{1}=2.7407, \quad r_{2}=-3.8678, \quad r_{3}=$ 2.0559 .

The parameters were established for Lithuania where climate conditions are similar to northern Poland. However, to test the goodness of fit of the model, 50 trees (representing whole dbh range) were cut on the sample plots. Following this, the length of the felled trees was measured as well as the diameters every $1 \mathrm{~m}$ along the trunk. The diameters obtained were compared with the Lee et al. (2003) formula based on dbh and tree height. The root mean square error (RMSE) for all the trees was $1.08 \mathrm{~cm}$, with range from 0.49 to $1.99 \mathrm{~cm}$. For all the measured diameters, $R^{2}=0.989(N=997)$.

All the simulated logs from the stems were classified into five assortment types based on their dimensions (Table 2). These assortment types included sawmill wood of third thickness class (SM3), sawmill wood of second thickness class (SM2), sawmill wood of first thickness class (SM1), pulpwood (PW) and energy wood (EW) from the tree tops. The total volume of each type of assortment was calculated as the sum of all the log volumes within the same assortment type on the sample plot. The volume calculation of one log was based on the top and bottom diameters and log length; top log volume was obtained from the cone formula.

Subsequently, based on the volume of each assortment type, the value in Euro (EUR) was determined. The assortment types were valued based on the average local timber sale prices in Polish Zloty (PLN), expressed finally in Euro (EUR $1=$ PLN 4.1981). For each of the 20 stands analysed, the arithmetic mean dbh, the quadratic mean dbh, the mean height and the top height (mean height of 50 trees with the biggest $\mathrm{dbh}$ for each sample plot) were determined, as well as the relative spacing (the ratio of the average distance between the trees to the average dominant height of the stand) by Wilson (1946), the basal area (in square metre per hectare), the merchantable volume (in cubic metre per hectare), the value of each assortment (in EUR) and the total value of all the assortments from all the trees (in EUR per hectare).

Statistical analyses were performed using the Stats and Agricolae packages of R software (R Core Team 2012). To determine the linear correlation between stand density

\begin{tabular}{|c|c|c|c|c|c|}
\hline Type of timber assortment & Symbol & $\begin{array}{l}\text { Middle diameter } \\
\text { (under bark), cm }\end{array}$ & $\begin{array}{l}\text { Small-end diameter } \\
\text { (under bark), cm }\end{array}$ & Length, m & $\begin{array}{l}\text { Price per cubic metre } \\
\text { (under bark), EUR }\end{array}$ \\
\hline Sawmill wood third thickness class & SM3 & $\geq 35$ & $\geq 14$ & 2.5 & 65.0 \\
\hline Sawmill wood second thickness class & $\mathrm{SM} 2$ & $25-34$ & $\geq 14$ & 2.5 & 56.9 \\
\hline Sawmill wood first thickness class & SM1 & $\leq 24$ & $\geq 14$ & 2.5 & 48.8 \\
\hline Pulpwood & PW & - & $\geq 5$ & 2.5 & 38.1 \\
\hline Energy wood (stem residuals) & EW & - & - & - & 13.6 \\
\hline
\end{tabular}
and selected stand parameters (arithmetic mean dbh,

Table 2 Parameters of timber assortment types used for stem wood classification 
mean height, stand merchantable volume and basal area), on the one hand, and timber assortment values (SM, PW, EW), on the other, Pearson's correlation coefficient matrix was used and the significance of the correlation coefficients found was verified. The analyses were preceded by the Cramer-von Mises normality test for all the variables analysed. A significance threshold of $\alpha=0.05$ was used for the tests.

\section{Results}

Using model simulation, the stems of all the trees on the 20 experimental plots were divided into sections, which were subsequently classified into one of five assortments (Table 2). For all the assortments, the total volume on the 0.5-ha experimental plots was calculated and converted into values per 1 ha. The mean volume ranged between 1.0 (SW3) and 145.5 (SW1) $\mathrm{m}^{3} \mathrm{ha}^{-1}$ (Table 3, Fig. 2).

For all the stands, the total value of all the assortments was calculated, which ranged between 4506 and 7610 EUR ha ${ }^{-1}$ (mean 6098). Pearson's coefficients were calculated for correlations between stand density and total timber value on the one hand and selected stand parameters on the other (Table 4). All the characteristics analysed had normal distributions at $p=0.05$.

Stand density did not correlate with the stand's merchantable volume or basal area. For correlations, arithmetic mean diameter was used, which depends on stand density. Quadratic mean diameter is more similar to basal area, which however does not correlate with density of the stand. A negative correlation was found with the arithmetic mean dbh, mean height and value of sawmill wood, while a positive correlation was found with the value of the pulpwood and value of the energy wood. The total value of the wood did not correlate significantly with the value of the pulpwood or value of the energy wood but was positively correlated with the arithmetic mean $\mathrm{dbh}$, mean height, stand volume, basal area and value of the sawmill wood (Table 4, Fig. 3).

The correlation between stand density and total value of the wood was very weak and not statistically significant $\left(R^{2}=0.105, p=0.159\right)$. Stand density was significantly correlated with the value of the sawmill wood $\left(R^{2}=0.280\right.$, $p=0.016)$, value of the pulpwood $\left(R^{2}=0.866, p<0.001\right)$ and value of the energy wood $\left(R^{2}=0.918, p<0.001\right)$.

\section{Discussion}

As expected, the mean $\mathrm{dbh}$ of the trees on the experimental plots had a strong $(p<0.001)$ negative correlation with the stand density (Table 1). This association is commonly known and has been reported by multiple authors (e.g. Alegria 2011; Dean et al. 2013; del Río et al. 2001; Kuliešis et al. 2010; Mäkinen and Isomäki 2004a, 2004b; Moulinier et al. 2015; Nilsson et al. 2010; Tang et al. 2016; Zeide 2010).

The mean tree height was also negatively correlated with stand density. The correlation was significant but weaker $(p=0.026)$ than with $\mathrm{dbh}$. Similar results were obtained by other authors, who reported that height was not as strongly correlated with stand density as dbh (Mäkinen and Isomäki 2004a; Stankova and Shibuya 2007; Valinger et al. 2000) or even that there was no correlation at all (Mäkinen et al. 2005).

No correlation was found between stand density and either stand basal area or merchantable volume (Table 1). Similar volumes of wood were found in all the stands analysed despite the differences in stand density (between 476 and 836 trees per hectare). This result confirmed the hypothesis that site quality ultimately determines the optimal level of productivity, i.e. similar volumes of mature stands, within a certain range of tree numbers and individual tree volumes.

When analysing the relationship between stand density and volume or basal area, two important factors need to be considered: (1) the age of the stand; and (2) the time from last thinning. For factor (1), the number of trees decreases, while volume and basal area increase with age. Therefore, density and basal area may be strongly correlated in stands of different ages (Gizachew and Brunner 2011). Comparisons between stands of different densities, but similar ages, yield different results. In these cases, basal area is not dependent on stand density, as corroborated by the present study and by other authors (Curtis et al. 1997; del Río et al. 2008). For factor (2), the heavier the thinning, the lower the number of trees remaining. Therefore, greater thinning intensity is associated with larger decreases in stand volume and basal area. These differences are only compensated for after several years, due to the intense growth of the remaining trees (Gizachew and Brunner 2011; Latham and Tappeiner 2002).

Table 3 The volume of the timber assortment types per 1 ha

\begin{tabular}{llllll}
\hline $\begin{array}{l}\text { Type of timber } \\
\text { assortment }\end{array}$ & $\begin{array}{l}\text { Minimum volume, } \\
\mathrm{m}^{3} \mathrm{ha}^{-1}\end{array}$ & $\begin{array}{l}\text { Maximum volume, } \\
\mathrm{m}^{3} \mathrm{ha}^{-1}\end{array}$ & $\begin{array}{l}\text { Mean volume, } \\
\mathrm{m}^{3} \mathrm{ha}^{-1}\end{array}$ & $\begin{array}{l}\text { Coefficient of variation } \\
\text { of mean volume }\end{array}$ & $\begin{array}{l}\text { Share of assortment } \\
\text { per ha, \% }\end{array}$ \\
\hline SM3 & 0.0 & 3.7 & 1.0 & 1.06 & 0.4 \\
SM2 & 16.2 & 89.6 & 50.6 & 0.41 & 19.7 \\
SM1 & 111.9 & 171.8 & 145.5 & 0.11 & 56.6 \\
PW & 33.2 & 84.9 & 56.2 & 0.24 & 21.9 \\
EW & 2.8 & 4.7 & 3.7 & 0.12 & 1.4 \\
\hline
\end{tabular}




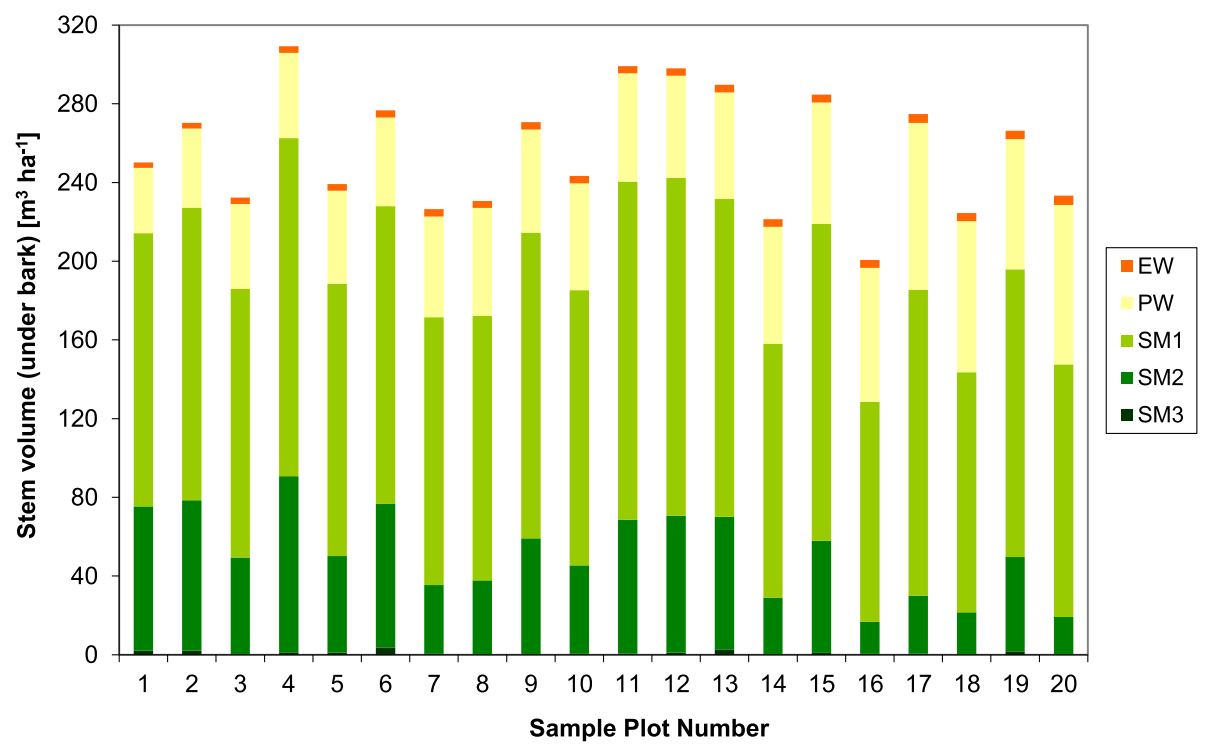

Fig. 2 Volume of timber assortments for the 20 experimental Scots pine plots. Plot numbers are as in Table 1; timber assortment symbols are as in Table 2

In the stands analysed, the total value of the wood was strongly correlated with arithmetic mean dbh $(r=0.711)$, which, in turn, correlated with stand density $(r=-0.850)$ (Table 3). On this basis, a correlation could also be expected between the total value of the wood and the stand density. However, this correlation proved to be very weak and not statistically significant (Fig. 3). What might have caused this? First of all, the total value of the wood includes the values of each assortment (SM3, SM2, SM1, PW and EW). The stand density was correlated negatively with the value of the sawmill wood and positively with the values of the pulpwood and energy wood (Fig. 3). These associations cancelled each other out. The second reason for the weak correlation might have been the small difference between the values of the sawmill wood in each thickness class: $€ 65.0, € 56.9$ and $€ 48.8$ for SM3, SM2 and SM1, respectively (Table 2). Larger differences between the assortment values would have resulted in a stronger correlation between the total value of the wood and the stand density (Kangas et al. 2010).

A previous pilot study (Bembenek et al. 2014), using the same experimental plots, investigated the value of the 10-m-long butt logs only (round wood, mainly saw logs) from individual trees and the total value per $100 \mathrm{~m}^{3}$ in three groups of stands with different densities. Statistically significant differences were found among these groups. The wood from the least dense groups of stands had the highest value, while that from the densest groups of stands had the lowest value. The present study was more detailed and compared values of assortments from whole stems, and without stand grouping. However, the results were not so clear in this case (Fig. 3). The observed differences between the two studies are also due to the fact that the analysis by Bembenek et al. (2014) did not include the top sections of the stems nor the assortment values (PW and EW), which were correlated with the stand density in a different way than in the case of the assortments from the lower sections of the stems (Table 3).

In some density ranges, a lower stand density could result in higher assortment values (Alegria 2011; Kojola et al. 2012; Zeide 2001). It is also important to note that the lower stand density obtained at the end of the growing period (before final felling) is a result of more

Table 4 Pearson's correlation coefficients for stand density and total value of wood and selected stand parameters on the 20 Scots pine sample plots

\begin{tabular}{|c|c|c|c|c|c|c|c|c|c|}
\hline Parameter & $\begin{array}{l}\text { Pearson's } \\
\text { correlation }\end{array}$ & $\begin{array}{l}\text { Arithmetic } \\
\text { mean dbh, cm }\end{array}$ & $\begin{array}{l}\text { Mean } \\
\text { height, m }\end{array}$ & $\begin{array}{l}\text { Merchantable } \\
\text { volume, } \mathrm{m}^{3} \mathrm{ha}^{-1}\end{array}$ & $\begin{array}{l}\text { Basal area, } \\
\mathrm{m}^{2} \mathrm{ha}^{-1}\end{array}$ & $\begin{array}{l}\text { Value of } \\
\text { sawmill wood, } \\
\text { EUR }\end{array}$ & $\begin{array}{l}\text { Value of } \\
\text { pulpwood, } \\
\text { EUR }\end{array}$ & $\begin{array}{l}\text { Value of } \\
\text { energy wood, } \\
\text { EUR }\end{array}$ & $\begin{array}{l}\text { Total value } \\
\text { of wood, EUR }\end{array}$ \\
\hline \multirow{2}{*}{$\begin{array}{l}\text { Stand } \\
\text { density }\end{array}$} & $r$ & -0.850 & -0.497 & -0.248 & -0.022 & -0.529 & 0.931 & 0.958 & -0.327 \\
\hline & $p$ & 0.000 & 0.026 & 0.291 & 0.927 & 0.016 & 0.000 & 0.000 & 0.159 \\
\hline \multirow{2}{*}{$\begin{array}{l}\text { Total value } \\
\text { of wood }\end{array}$} & $r$ & 0.711 & 0.780 & 0.996 & 0.844 & 0.970 & -0.387 & -0.255 & - \\
\hline & $p$ & 0.000 & 0.000 & 0.000 & 0.000 & 0.000 & 0.092 & 0.278 & - \\
\hline
\end{tabular}



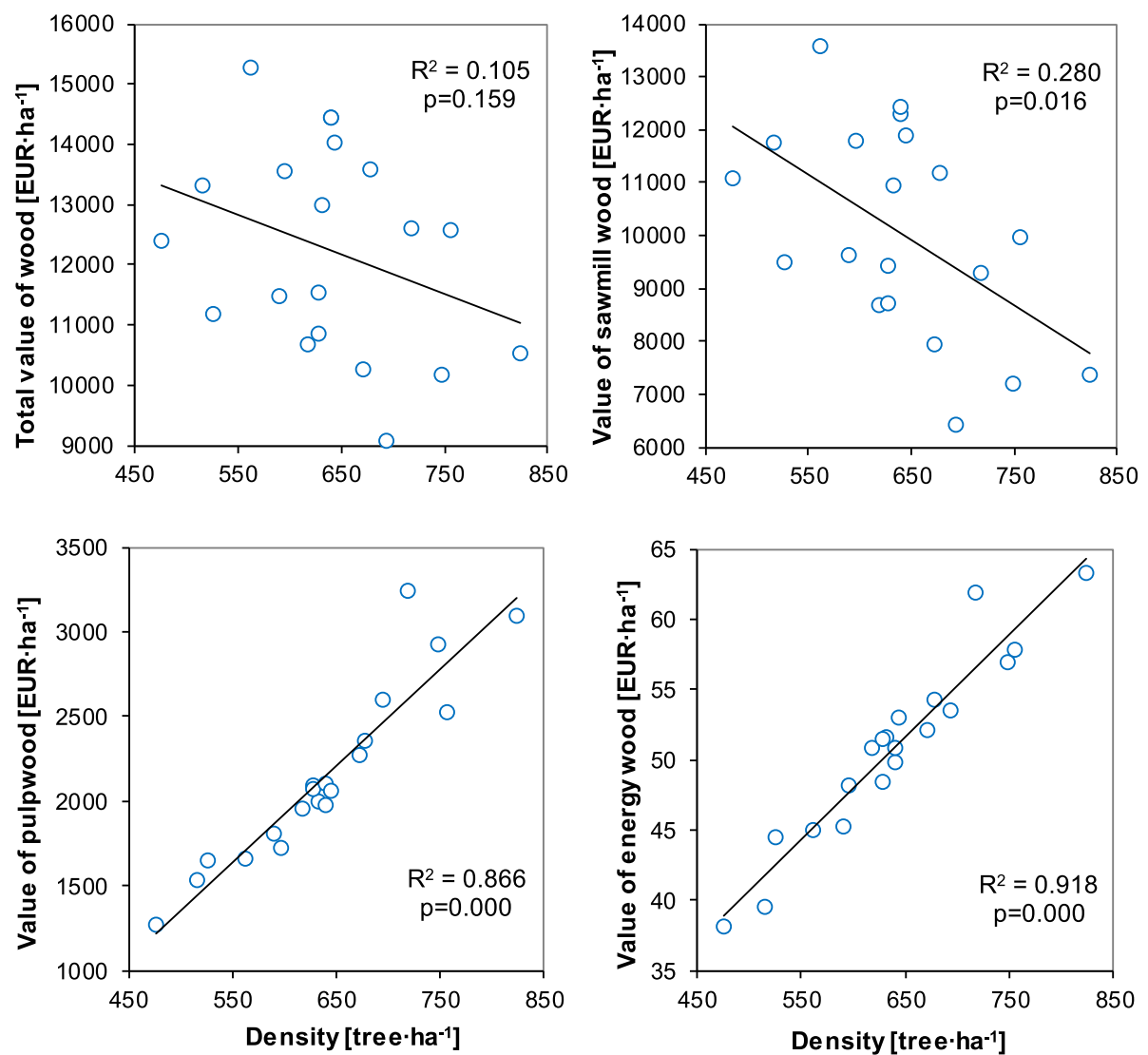

Fig. 3 Correlations between value of wood and stand density in Scots pine stands, for all assortments combined, and for sawmill wood, pulpwood and energy wood separately

intensive thinning during earlier periods of stand development. Therefore, more income was collected from the stands currently characterised by lower density. Unfortunately, it was not possible to reconstruct the history of the analysed stands in order to find out how much timber was obtained from thinning operations throughout the life of the stands. However, it is likely that more timber was collected, and thus more income generated, from the stands that, at the moment, are the least dense.

Trees grown in stands of lower densities are particularly important for sawmill wood production. After wood quality, tree dimensions are the most important factor affecting value of sawn timber: the larger the diameter, the higher the price (Carino and Biblis 2009; Mäkinen and Isomäki 2004a; Pasalodos-Tato and Pukkala 2007; Ranković et al. 2013). Moreover, harvesting trees with larger diameters increases productivity (Mederski et al. 2016) and decreasing costs (Karlsson et al. 2015; Mederski 2006; Moulinier et al. 2015) as fewer trees are required to obtain a given volume of wood.

In contrast, higher stand densities may be more beneficial for pulpwood and biomass end uses (Carino and Biblis 2003; Mäkinen et al. 2005; Routa et al. 2012).
Timber assortment value also depends on wood quality. Here, stand density has a bi-directional impact. On the one hand, trees growing in denser stands may produce better quality wood due to smaller knots and slower growth (Carino and Biblis 2009; Grace et al. 2015; Mäkinen et al. 2005). On the other hand, thinning, which decreases stand density, often eliminates low-quality trees (Gizachew and Brunner 2011; Zeide 2001).

In the present study, the total value of the wood correlated with arithmetic mean dbh, mean height, stand volume and basal area. However, stand density correlated only with arithmetic mean $\mathrm{dbh}$ and mean height (Table 4). This result demonstrates the complexity of the relationships among parameters, meaning that decisions concerning the optimisation of stand density require the consideration of a variety of factors. First of all, one must identify the final product that is to be obtained. If sawmill wood is the primary focus of production, maintaining a lower stand density index could be more beneficial, especially in older stands, where the risk of growing trees with excessively thick branches is lower. This strategy makes it possible to obtain the highest quality wood from optimal habitats (Wąsik et al. 2016). 


\section{Conclusions}

The strong correlation between the stand density and arithmetic mean dbh indicates that by implementing thinning at various intensities and frequencies, it is possible to grow stands of different densities, which in turn affects the structure of the timber assortments obtained. The lack of correlation between the stand density and basal area and volume means that the trees remaining in the stand after thinning compensate for the losses by growing faster.

The value of the wood was found to be correlated with the $\mathrm{dbh}$, tree height, basal area and stand volume. This means that the dimensional structure of trees is a significant factor in the economic aspects of timber production. The value of the sawmill wood was negatively correlated with the stand density, while the values of the pulpwood and energy wood were positively correlated with the density. This indicates that lower densities are more beneficial in sawmill wood production, while higher densities may be more beneficial in biomass production. However, for very accurate financial differences in the timber value obtained from stands of different density, wood defects and log quality should also be considered.

\section{Abbreviations \\ dbh: Diameter at breast height; EW: Energy wood; PW: Pulpwood; SM1: Sawmill wood of first thickness class (mid-diameter up to $24 \mathrm{~cm}$ under bark); SM2: Sawmill wood of second thickness class (mid-diameter between 25 and $34 \mathrm{~cm}$ under bark); SM3: Sawmill wood of third thickness class (mid-diameter $35 \mathrm{~cm}$ and higher under bark)}

\section{Acknowledgements}

The authors would like to thank the participants of the International Scientific Camps for Forestry Students ForseenPOMERANIA for their valuable contribution to the laborious field studies on research plots in Drawno Forest District (Pomerania Region, Poland).

\section{Funding}

This study was carried out as part of the Interreg IVa project: "Development of a trans-border decision support system for remote and model assessment of forest dendromass in the Pomerania Region" which was co-financed by the European Union through the European Regional Development Fund (INT-09-0039) and the Polish Ministry of Science and Higher Education (2171/ ForseenPOMERANIA/2011/2).

\section{Availability of data and materials}

Please contact author for data requests.

\begin{abstract}
Authors' contributions
AW was responsible for the formulation of the methods, data collection, preparation of the manuscript, text corrections and work coordination. MB participated in the methods formulation and data collection and contributed to the text of the manuscript. A $Ł$ designed and performed statistical analysis and contributed to the interpretation of the results. PM participated in the formulation of the methods, participated in the data collection and contributed to the manuscript writing and final corrections. All authors read and approved the final manuscript.
\end{abstract}

Ethics approval and consent to participate Not applicable.

Consent for publication

Not applicable.

\section{Competing interests}

The authors declare that they have no competing interests.

\section{Publisher's Note}

Springer Nature remains neutral with regard to jurisdictional claims in published maps and institutional affiliations.

\section{Author details}

${ }^{1}$ Faculty of Forestry, Department of Forest Management, Poznań University of Life Sciences, Wojska Polskiego 71C, 60-625 Poznań, Poland. Faculty of Forestry, Department of Forest Utilisation, Poznań University of Life Sciences, Wojska Polskiego 71A, 60-625 Poznań, Poland. ${ }^{3}$ Faculty of Agronomy and Bioengineering, Department of Mathematical and Statistical Methods, Poznań University of Life Sciences, Wojska Polskiego 28, 60-637 Poznań, Poland.

Received: 23 March 2018 Accepted: 14 September 2018

Published online: 27 September 2018

\section{References}

Alegria, C. (2011). Simulation of silvicultural scenarios and economic efficiency for maritime pine (Pinus pinaster Aiton) wood-oriented management in centre inland of Portugal. Forest Systems, 20(3), 361-378. https://doi.org/10.5424/fs/ 20112003-11070.

Bembenek, M., Karaszewski, Z., Kondracki, K., Łacka, A., Mederski, P. S., Skorupski, M., Strzeliński, P., Sułkowski, S., \& Węgiel, A. (2014). Value of merchantable timber in Scots pine stands of different densities. Drewno, 57(192), 133-142. https://doi.org/10.12841/wood.1644-3985.S14.09.

Borecki, T., Stępien, E., Wójcik, R., \& Orzechowski, M. (2016). Verification of the principles of accounting for the size of the allowable fellings in forest management planning. Drewno, 59(197), 61-75. https://doi.org/10.12841/ wood.1644-3985.C34.07.

Bruchwald, A. (1969). Badania zależności grubości kory od pierśnicy w drzewostanach sosnowych. Folia Forestalia Polonica, 15, 171-184.

Carino, H. F., \& Biblis, E. J. (2003). Expected volume and value of structuraldimension lumber from 25-, 30-, 35-, 40- and 50-year-old loblolly pine plantation timber. In A. Amaro, D. Reed, \& P. Soares (Eds.), Modelling Forest Systems (pp. 325-333). Wallingford: CABI Publishing. https://www.researchgate. net/profile/Margarida_Tome3/publication/235004892_GLOBTREE_an_ individual_tree_growth_model_for_Eucalyptus_globulus_in_Portugal/links/ 0a85e532d397d186d0000000.pdf.

Carino, H. F., \& Biblis, E. J. (2009). Impact of stand density on the quality and value of 35-year-old loblolly pine plantation sawtimber: a case study. Forest Products Journal, 59(3), 62-66.

Castedo-Dorado, F., Crecente-Campo, F., Álvarez-Álvarez, P., \& Barrio-Anta, M. (2009). Development of a stand density management diagram for radiata pine stands including assessment of stand stability. Forestry, 82(1), 1-16. https://doi.org/10.1093/forestry/cpm032.

Curtis, R. O., Marshall, D. D., \& Bell, J. F. (1997). LOGS: a pioneering example of silvicultural research in coast Douglas-fir. Journal of Forestry, 95(7), 19-25.

Czajka, M., \& Fabisiak, E. (2016). Radial variation of macrostructural parameters and density of wood in dominant trees of coniferous species. Drewno, 59(197), 179-187. https://doi.org/10.12841/wood.1644-3985.C21.17.

Dean, T. J., Roberts, S. D., \& Seymour, R. S. (2013). Toward developing a direct relation between gross volume increment and stand density. Canadian Journal of Forest Research, 43(9), 852-860. https://doi.org/10.1139/cjfr-2013-0038.

del Río, M., Calama, R., Cañellas, l., Roig, S., \& Montero, G. (2008). Thinning intensity and growth response in SW-European Scots pine stands. Annals of Forest Science, 65(3). https://doi.org/10.1051/forest:2008009.

del Río, M., Montero, G., \& Bravo, F. (2001). Analysis of diameter-density relationships and self-thinning in non-thinned even-aged Scots pine stands. Forest Ecology and Management, 142(1-3), 79-87. https://doi.org/10.1016/ s0378-1127(00)00341-8.

Egnell, G., \& Ulvcrona, K. A. (2015). Stand productivity following whole-tree harvesting in early thinning of Scots pine stands in Sweden. Forest Ecology and Management, 340, 40-45. https://doi.org/10.1016/j.foreco.2014.12.017.

Giuggiola, A., Bugmann, H., Zingg, A., Dobbertin, M., \& Rigling, A. (2013). Reduction of stand density increases drought resistance in xeric Scots pine forests. Forest Ecology and Management, 310, 827-835. https://doi.org/10. 1016/j.foreco.2013.09.030. 
Gizachew, B., \& Brunner, A. (2011). Density-growth relationships in thinned and unthinned Norway spruce and Scots pine stands in Norway. Scandinavian Journal of Forest Research, 26(6), 543-554. https://doi.org/10.1080/02827581. 2011.611477.

Grace, J. C., Brownlie, R. K., \& Kennedy, S. G. (2015). The influence of initial and post-thinning stand density on Douglas-fir branch diameter at two sites in New Zealand. New Zealand Journal of Forestry Science, 45: 14. https://doi.org/ 10.1186/s40490-015-0045-8

Hurttala, H., Cao, T. J., \& Valsta, L. (2017). Optimization of Scots pine (Pinus sylvestris) management with the total net return from the value chain. Journal of Forest Economics, 28, 1-11. https://doi.org/10.1016/j.jfe.2017.04.001.

Hyytiäinen, K., Ilomäki, S., Mäkelä, A., \& Kinnunen, K. (2006). Economic analysis of stand establishment for Scots pine. Canadian Journal of Forest Research, 36(5), 1179-1189. https://doi.org/10.1139/x06-023.

Kangas, A., Mäkinen, H., \& Lyhykäinen, H. T. (2010). Value of quality information of Scots pine stands in timber bidding. Canadian Journal of Forest Research, 40(9), 1781-1790. https://doi.org/10.1139/×10-093.

Karlsson, L., Nyström, K., Bergström, D., \& Bergsten, U. (2015). Development of Scots pine stands after first biomass thinning with implications on management profitability over rotation. Scandinavian Journal of Forest Research, 30(5), 416-428. https://doi.org/10.1080/02827581.2015.1023351.

Kojola, S., Ahtikoski, A., Hökkä, H., \& Penttilä, T. (2012). Profitability of alternative management regimes in Scots pine stands on drained peatlands. European Journal of Forest Research, 131(2), 413-426. https://doi.org/10.1007/s10342-011-0514-4.

Kuliešis, A., Saladis, J., \& Kuliešis, A. A. (2010). Development and productivity of young Scots pine stands by regulating density. Baltic Forestry, 16(2), 235-246.

Latham, P., \& Tappeiner, J. (2002). Response of old-growth conifers to reduction in stand density in western Oregon forests. Tree Physiology, 22(2-3), 137-146.

Lee, W. K., Seo, J. H., Son, Y. M., Lee, K. H., \& von Gadow, K. (2003). Modeling stem profiles for Pinus densiflora in Korea. Forest Ecology and Management, 172(1), 69-77. https://doi.org/10.1016/s0378-1127(02)00139-1.

Mäkinen, H., Hynynen, J., \& Isomäki, A. (2005). Intensive management of Scots pine stands in southern Finland: First empirical results and simulated further development. Forest Ecology and Management, 215(1-3), 37-50. https://doi. org/10.1016/j.foreco.2005.03.069.

Mäkinen, H., \& Isomäki, A. (2004a). Thinning intensity and growth of Scots pine stands in Finland. Forest Ecology and Management, 201(2-3), 311-325. https:// doi.org/10.1016/j.foreco.2004.07.016.

Mäkinen, H., \& Isomäki, A. (2004b). Thinning intensity and long-term changes in increment and stem form of Scots pine trees. Forest Ecology and Management, 203(1-3), 21-34. https://doi.org/10.1016/j.foreco.2004.07.028.

Mederski, P. S. (2006). A comparison of harvesting productivity and costs in thinning operations with and without midfield. Forest Ecology and Management, 224(3), 286-296. https://doi.org/10.1016/j.foreco.2005.12.042.

Mederski, P. S., Bembenek, M., Karaszewski, Z., Giefing, D. F., Sulima-Olejniczak, E., Rosińska, M., \& Łacka, A. (2015). Density and mechanical properties of Scots pine (Pinus sylvestris L.) wood from a seedling seed orchard. Drewno, 58(195), 117-124. https://doi.org/10.12841/wood.1644-3985.123.10.

Mederski, P. S., Bembenek, M., Karaszewski, Z., Łacka, A., Szczepańska-Álvarez, A., \& Rosińska, M. (2016). Estimating and modelling harvester productivity in pine stands of different ages, densities and thinning intensities. Croatian Journal of Forest Engineering, 37(1), 27-36.

Moulinier, J., Brais, S., Harvey, B. D., \& Koubaa, A. (2015). Response of boreal Jack pine (Pinus banksiana Lamb.) stands to a gradient of commercial thinning intensities, with and without N fertilization. Forests, 6(8), 2678-2702. https:// doi.org/10.3390/f6082678.

Näslund, M. (1929). Antalet provträd och hójdkurvans noggrannhet. Meddelanden från Statens Skogsförsöksanstalt, 25, 3 .

Niemistö, P. (2013). Effect of growing density on biomass and stem volume growth of downy birch stands on peatland in Western and Northern Finland. Silva Fennica, 47(4). https://doi.org/10.14214/sf.1002

Nilsson, U., Agestam, E., Ekö, P.-M., Elfving, B., Fahlvik, N., Johansson, U., Karlsson, K., Lundmark, T., \& Wallentin, C. (2010). Thinning of Scots pine and Norway spruce monocultures in Sweden. Studia Forestalia Suecica, 219, 1-46.

Pasalodos-Tato, M., \& Pukkala, T. (2007). Optimising the management of evenaged Pinus sylvestris L. stands in Galicia, north-western Spain. Annals of Forest Science, 64(7), 787-798. https://doi.org/10.1051/forest:2007059.

Petrauskas, E., Rupsys, P., \& Memgaudas, R. (2011). Q-exponential variable-form of a stem taper and volume model for Scots pine (Pinus sylvestris L.) in Lithuania. Baltic Forestry, 17(1), 118-127.
R Core Team (2012). R: A language and environment for statistical computing. R Foundation for Statistical Computing, Vienna, Austria. http://www.R-project.org/.

Ranković, N., Pantić, D., \& Keča, L. (2013). Relationship between the values of beech timber (Fagus L.) and tree dimensions in forest thinning in Serbia. Baltic Forestry, 19(1), 152-160.

Routa, J., Kellomäki, S., \& Strandman, H. (2012). Effects of forest management on total biomass production and $\mathrm{CO}_{2}$ emissions from use of energy biomass of Norway spruce and Scots pine. Bioenergy Research, 5(3), 733-747. https://doi. org/10.1007/s12155-012-9183-5

Rymer-Dudzińska, T. (1994). New empirical formulas for hight curves of Scots pine. Sylwan, 138(11), 21-24.

Stankova, T. V., \& Shibuya, M. (2007). Stand density control diagrams for Scots pine and Austrian black pine plantations in Bulgaria. New Forests, 34(2), 123 141. https://doi.org/10.1007/s11056-007-9043-x.

Tahvonen, O., Pihlainen, S., \& Niinimäki, S. (2013). On the economics of optimal timber production in boreal Scots pine stands. Canadian Journal of Forest Research, 43(8), 719-730. https://doi.org/10.1139/cjfr-2012-0494.

Tang, X. L., Perez-Cruzado, C., Vor, T., Fehrmann, L., Álvarez-González, J. G., \& Kleinn, C. (2016). Development of stand density management diagrams for Chinese fir plantations. Forestry, 89(1), 36-45. https://doi.org/10.1093/forestry/cpv024.

Valinger, E., Elfving, B., \& Mörling, T. (2000). Twelve-year growth response of Scots pine to thinning and nitrogen fertilisation. Forest Ecology and Management, 134(1-3), 45-53. https://doi.org/10.1016/s0378-1127(99)00244-3.

Wasik, R., Michalec, K., \& Mudryk, K. (2016). Variability in static bending strength of the "Taborz" Scots pine wood (Pinus sylvestris L.). Drewno, 59(196), 153-162. https://doi.org/10.12841/wood.1644-3985.132.11.

Wilson, F. G. (1946). Numerical expression of stocking in terms of height. Journal of Forestry, 44, 758-761.

Zeide, B. (2001). Thinning and growth: a full turnaround. Journal of Forestry, 99(1), 20-25.

Zeide, B. (2004). Optimal stand density: a solution. Canadian Journal of Forest Research, 34(4), 846-854. https://doi.org/10.1139/x03-258.

Zeide, B. (2010). Comparison of self-thinning models: an exercise in reasoning. Trees - Structure and Function, 24(6), 1117-1126. https://doi.org/10.1007/ s00468-010-0484-z

Zhang, J., Oliver, W. W., \& Ritchie, M. W. (2007). Effect of stand densities on stand dynamics in white fir (Abies concolor) forests in Northeast California, USA. Forest Ecology and Management, 244(1-3), 50-59. https://doi.org/10.1016/j. foreco.2007.03.036

\section{Submit your manuscript to a SpringerOpen ${ }^{\circ}$ journal and benefit from:}

- Convenient online submission

- Rigorous peer review

- Open access: articles freely available online

High visibility within the field

Retaining the copyright to your article

Submit your next manuscript at $>$ springeropen.com 